\title{
Sol Üst Lob Evre I Akciğer Kanserli Hastalar İçin Sol Üst Lobektomi Aşırı Tedavi mi? Propensity Skor Analizi
}

\author{
Hüseyin MELEK ${ }^{1}$, Tolga Evrim SEVINCÇ ${ }^{1}$, Deniz SIĞIRLI ${ }^{2}$, Ahmet Sami BAYRAM ${ }^{1}$, \\ Cengiz GEBITTEKIN ${ }^{1}$
}

1 Bursa Uludağ Üniversitesi Tıp Fakültesi, Göğüs Cerrahisi Anabilim Dalı, Bursa.

2 Bursa Uludağ Üniversitesi Tıp Fakültesi Biyoistatistik Anabilim Dalı, Bursa.

ÖZET

Sol üst lobda yer alan küçük hücreli dışı akciğer kanseri (KHDAK) için sol üst lobektomi ve segmentektomi sonuçlarını karşılaștırmayı amaçladık. Kliniğimizde 1999-2016 yılları arasında sol üst lob yerleşimli KHDAK nedeniyle segmentektomi veya lobektomi uygulanan hastaların verilerini retrospektif olarak inceledik. Segmentektomi; lobektomi için uygun evre I hastalar ve sınırlı kardiyopulmoner rezervi nedeniyle lobektomi için uygun olmayan hastalarda uygulandı. Toplamda 127 hasta optimal veri eşleştirme algoritması kullanılarak propensity skoru analizine dahil edildi. 1: 2 eşleştirme algoritmasından sonra 90 hasta iki gruba ayrıldı; grup 1 segmentektomi (n=30) ve grup 2 lobektomi ( $\mathrm{n}=60)$. Morbidite, mortalite, uzun dönem sağkalım oranları ve prognostik faktörler analiz edildi. Histopatolojik incelemede 57 hasta evre I [grup $1(\mathrm{n}=18)$, grup $2(\mathrm{n}=39)$ ], 33 hasta evre II-IV [grup $1(\mathrm{n}=12)$, grup $2(\mathrm{n}=21)$ ] tespit edildi. Morbidite oran1 \% 37.78 (37/90) [grup 1: $\mathrm{n}=11(\% 36.67)$, grup $2: \mathrm{n}=23(\% 38.33), \mathrm{p}=1.000$ ] ve mortalite oran1 $\% 1.11$ [grup $1: \mathrm{n}=1(\% 3.33)$, grup $2: \mathrm{n}=0(\% 0)$, p = 0.333] idi. Evre I hastalarda ortalama Kaplan-Meier sağkalım süresi grup 1 için 146.09 (\% 95 CI: 111.70-180.49) ve grup 2 için 106.99 (\% 95 CI: 77.68-136.30) idi $(\mathrm{p}=0.185)$ olarak sonuçlandı. Bu çalışmada sol üst lobda segmentektomi veya lobektomi uygulanan erken evre KHDAK'li hastalar için benzer sonuçlar elde edildi. Özellikle lingulektomi veya trisegmentektomi, evre I KHDAK için lobektomiye kyyasla standart bir prosedür olarak önerilmektedir.

Anahtar Kelimeler: Trisegmentektomi. Lingulektomi. Sol üst lobektomi. Akciğer rezeksiyonu.

Is Left Upper Lobectomy an Overtreatment for Patients with Stage I Lung Cancer in the Left Upper Lobe? A Propensity ScoreMatched Analysis.

\begin{abstract}
We aim to compare the outcomes of left upper lobectomy and segmentectomy for non-small cell lung cancer (NSCLC) located at the left upper lobe. We retrospectively reviewed the medical data of patients with NSCLC located in the left upper lobe who underwent segmentectomy or lobectomy between 1999 and 2016. Segmentectomy was preferred for patients with stage I who were also eligible for lobectomy and for patients who were not eligible for lobectomy due to limited cardiopulmonary reserve. In total, 127 patients were included into the propensity score analysis by using optimal data matching algorithm. After the 1:2 matching algorithm, 90 patients were divided into two groups; group 1 segmentectomy $(\mathrm{n}=30)$, and group 2 lobectomy $(\mathrm{n}=60)$. The morbidity, mortality, long-term survival rates and prognostic factors were analyzed. Histopathological investigation revealed 57 patients as stage I [group $1(n=18)$, group $2(n=39)$ ], 33 patients as stage II-IV [group $1(\mathrm{n}=12)$, group $2(\mathrm{n}=21)$ ]. Morbidity rate was 37.78\% (37/90) [group 1: $\mathrm{n}=11$ (36.67\%), group 2: $\mathrm{n}=23$ (38.33\%), $\mathrm{p}=1.000$ ] along with mortality rate of $1.11 \%$ [group $1: \mathrm{n}=1(3.33 \%)$, group $2: \mathrm{n}=0(0 \%), \mathrm{p}=0.333$ ]. In stage I patients, mean Kaplan-Meier survival time was 146.09 (95\%CI: 111.70-180.49) for group I and 106.99 (95\%CI: 77.68-136.30) for group 2 ( $\mathrm{p}=0.185)$. This study revealed similar outcomes for patients with early stage NSCLC located at the left upper lobe undergoing either segmentectomy or lobectomy. In particular, lingulectomy or trisegmentectomy is recommended as a standard procedure for Stage I NSCLC compared to lobectomy.
\end{abstract}

Key Words: Trisegmentectomy. Lingulectomy. Left upper lobectomy. Lung resection.

Geliş Tarihi: 24.Nisan.2021

Kabul Tarihi: 26.Ağustos.2021

Dr. Tolga Evrim SEVINÇ

Bursa Uludağ Üniversitesi Tıp Fakültesi,

Göğüs Cerrahisi Anabilim Dalı,

Bursa.

Tel.: +90 5517152415

E-posta: tes3408@gmail.com
Yazarların ORCID ID Bilgisi:

Hüseyin MELEK: 0000-0003-1822-8153

Tolga Evrim SEVINÇ: 0000-0002-0150-0782

Deniz SIĞIRLI: 0000-0002-4006-3263

Ahmet BAYRAM: 0000-0003-0684-0900

Cengiz GEBITEKIN: 0000-0001-8718-9499 
Yetmiş yıl önce, pnömonektomi küçük hücreli dışı akciğer kanseri (KHDAK) için standart cerrahi prosedür olarak kabul edilirken, lobektomi ancak akciğer rezervi kisıtlı olan hastalarda uygulanmaktaydı. Daha sonraki yıllarda, lobektominin daha az mortaliteyle pnömonektomiye benzer sağkalım oranı sağladığ 1 tespit edildi ${ }^{1}$. Akciğer Kanseri Çalışma Grubunun 1995 yılında yayınlamış olduğu prospektif randomize kontrollü çalışmanın sonuçlarına göre sublobar rezeksiyon yapılan hastalarda lobektomiye kıyasla lokal hastalık rekürrensinin üç kat daha fazla olduğu gösterildi $^{2}$. Bu çalışmadan sonra lobektomi KHDAK için standart cerrahi tedavi yöntemi olarak kabul edildi ${ }^{3}$. Ancak bu çalışmada sublobar rezeksiyon grubunda segmentektomi uygulanan hastaların yanında wedge (kama) rezeksiyon uygulanan çok sayıda hasta yer almaktaydı. Son yıllarda teknolojideki gelişmeler ve artan ortalama yaşam süresi, erken evre akciğer kanseri tanısı alan hasta sayısının artmasına, nüks, metakron akciğer kanseri ve yaşlı hastalarda akciğer kanserine rastlanma yaygınlığına yol açtı. Bu nedenlerle birçok cerrah, solunum fonksiyonu üzerinde daha az etkisi olan, lobektomiye göre daha düşük morbidite/mortalite ve en az lobektomiye eşit onkolojik fayda sağlayan akciğer rezeksiyon yöntemlerini araştırmaya başladı. Son yirmi yılda segmental rezeksiyon ve lobektomiyi karşılaştıran birçok çalışma yayınlandı. $\mathrm{Bu}$ çalışmaların sonucu olarak günümüzde segmentektominin seçilmiş hastalarda (düşük akciğer fonksiyonu nedeniyle lobektominin kontraendike olduğu, periferik yerleşimli ve $\leq 2 \mathrm{~cm}$ tümörler, ve belirtilen özelliklerden en az biri ile: saf adenokarsinoma in situ histolojisi, Toraks Bilgisayarlı Tomografide (BT) \% 50'den fazla buzlu cam görünümü içeren nodüller ve uzun doubling time) yapılması önerilmektedir ${ }^{4}$.

Sağ ve sol akciğerler arasındaki anatomik farklılık nedeniyle cerrahi prosedür olarak farklı tanımlansa da sol üst lob trisegmentektomi (TS/S1-3 segmentekto$\mathrm{mi} /$ üst divizyonektomi), sağ üst lobektomiye, lingulektomi (L/S4-5 segmentektomi) ise orta lobektomiye eşdeğerdir ${ }^{5}$. Ancak bu gerçek, çalışmalarda göz ard1 edilmiştir. Anatomik karşılaştırmaları dikkate alan bir çalışma Houck ve arkadaşları tarafından yapılmış olup, sol üst lob apikal yerleşimli küçük tümörler için standart cerrahi tedavi olarak TS'yi önermişlerdir ${ }^{6}$. Hatta yazarlar, seçilmiş hastalarda TS yerine sol üst lobektominin aşırı tedavi olabileceğini belirtmişlerdir. Kliniğimizde 2007 yılından bu yana, seçilmiş hastalarda tercih ettiğimiz yaklaşım sol üst lobektomi yerine parankim koruyucu cerrahidir. Bu çalışmanın amacı sol akciğer üst lob yerleşimli evre I KHDAK hastalarda üst lobektomi ve parankimal koruyucu cerrahi (TS veya L) sonuçlarını karşılaştırmaktır.

\section{Gereç ve Yöntem}

Etik kurulu onamı alınarak (Karar No: 2020-9/20, 27.05.2020) 1999-2016 yılları arasında anatomik pulmoner rezeksiyon (segmentektomi veya lobektomi) yapılan sol üst lobda yerleşimli KHDAK'li hastaların tıbbi verileri retrospektif olarak analiz edildi. Klinik evreleme, BT, kemik sintigrafisi, abdominal ultrasonografi ve 2006'dan sonra pozitron emisyon tomografisi (PET/CT) kullanılarak yapıldı. Semptomatik hastalarda kraniyal MR görüntülemesi, mediastinal lenf nodu metastaz şüphesi olan hastalarda invazif mediastinal evreleme için endobronşiyal ultrason, mediastinoskopi, mediastinotomi yöntemleri tercih edildi. Uygun hastalara cerrahi tedavi teklif edildi. Segmentektomi, sol üst lobektomi için uygun olan klinik evre I KHDAK hastalarda ve sinırlı kardiyopulmoner rezervi ve ciddi komorbiditesi nedeniyle lobektomiye uygun olmayan hastalarda tercih edildi. Belirtilen kriterlere uyan hastalardan segmentektominin risk ve faydalarını açıklayan bilgilendirilmiş onam ve tüm hastalardan ameliyat için onam alındı. Akciğer rezeksiyonu video yardımlı torakoskopi (VATS) veya tam kas koruyucu mini torakotomi kullanılarak yapıldı. Rezeke edilecek segmentin parankim sınırı, segment bronşunun klemplenmesi ve hastanın yeniden ventile edilmesiyle belirlendi. Fissür veya segmentler stapler kullanılarak ayrıldı. Segmentektomi sirasında, lobektomiye geçme kararı, peribronşiyal veya segmentler arası lenf düğümlerinin frozen patoloji sonuçlarına ve bunların akciğer kanseri metastazı için pozitif olup olmadığına göre verildi. Ayrıca segmentektominin parankimal cerrahi sınırları tümöre iki cm'den az olduğu taktirde lobektomi yapıldı. Tüm hastalara ek olarak mediastinal lenf nodu diseksiyonu yapıldı. Plevral çadır, pnömoperiton ve geçici frenik sinir paraliz yöntemleri kullanılmadı. Beş günden fazla süren hava kaçağı, uzamış hava kaçağı (UHK) olarak kabul edildi. Operasyondan 72 saat sonra çekilen akciğer grafisinde visseral plevra ile gögüs duvarı arasında \% 20 veya $3 \mathrm{~cm}$ 'den fazla pnömotoraks olmas1 plevral boşluk olarak kabul edildi. Perioperatif mortalite, ameliyattan sonraki ilk 30 gün içinde meydana gelen ölüm veya ilgili akciğer rezeksiyon ameliyatı için hastanede kalış sırasında meydana gelen ölüm olarak tanımlandı. Doksan günlük ölüm oranı da hesapland. Patolojik evreleme, TNM evrelemesinin 8. baskısı kullanılarak yapıldı. N1 hastalığı olan hastalar adjuvan kemoterapi alırken, N2 hastalığ1 için kemoradyoterapi verildi. Ayrıca adenokarsinom veya büyük hücreli karsinom tanısı alan $4 \mathrm{~cm}$ 'den büyük tümörleri olan hastalara da adjuvan kemoterapi verildi. Tüm hastalar ameliyat sonrası ilk iki yıl üç ay ve sonrasında 6 ay arayla BT çekilerek takip edildi. Lokal rekürrens segmentektomi hastalarında ipsilateral lob, hilum veya mediastende herhangi bir rekürrens gelişmesi olarak tanımlanırken, lobektomi hastalarında herhangi bir hiler veya mediastinal yapıda rekürrens gelişmesi olarak tanımlandı. Uzak nüks, ipsilateral akciğerin farklı lobunda herhangi bir nüks, kontralateral mediasten veya hilumun veya ekstratorasik metastaz olarak 


\section{Sol Üst Lobektomi Evre I KHDAK İçin Aşırı Tedavi mi?}

tanımlandı ${ }^{7}$. Sağkalım, ameliyattan ölüme veya son takibe kadar geçen süre olarak belirlendi.

Aşağıdaki kriterlere sahip hastalar çalışmadan çıkarıld1:

1. $\mathrm{TS} / \mathrm{L}$ dişındaki segmentektomiler (S1, S1+2 gibi)

2. Ekstended rezeksiyonlu hastalar (vertebra, göğüs duvarı, bronşiyal-arteriyel sleeve, intraperikardiyal vb.)

Toplamda 127 hasta, optimal veri eşleştirme algoritması kullanılarak eğilim skoru analizine dahil edildi. 1:2 eşleştirme algoritmasından sonra 90 hasta iki gruba ayrıld1; grup 1 segmentektomi $(n=30)$, grup 2 lobektomi $(n=60)$. Cinsiyet, yaş, birinci saniyedeki zorlu ekspiratuar volüm (FEV1), VATS, komplikasyon, tümör histopatolojik tipi, TNM evresi (tümör boyutu, lenf nodu metastaz varlığı), adjuvan tedavi ve karıştırıcı değişkenler için propensity skoru eşleştirmesi yapıldı. Morbidite, 30-90 günlük mortalite, sağkalım oranları ve prognostik faktörler analiz edildi.

\section{Istatistik Analizi}

Sürekli değişkenlerin normalliği Shapiro-Wilk testi ile test edildi. Normal dağılım gösteren değişkenler için sürekli değişkenler ortalama \pm standart sapma olarak sunuldu, aksi takdirde medyan (minimum-maksimum) değerler verildi. Sırasıyla normal dağılımlı ve normal olmayan değişkenler için iki bağımsız grubu karşılaştırmak için bağımsız örnekler $\mathrm{t}$ testi veya MannWhitney $U$ testi yapıldı. Kategorik değişkenler frekanslar ve yüzdelerle ifade edildi. Gruplar arası karş1laştırmalar Pearson Ki-kare testi, Fisher'ın kesin kikare testi ve kategorik değişkenler için FisherFreeman-Halton testi ile yapıldı. Genel sağkalım, Kaplan-Meier yöntemiyle tahmin edildi ve iki örneğin sağkalım dağılımlarını karşılaştırmak için log-rank testi kullanıldı. Anlamlılık düzeyi $\alpha=0.05$ olarak alındı. İstatistiksel analizler IBM SPSS Statistics 21.0 (IBM Corp., USA) ve NCSS version 10 (Hintze J. NCSS LLC.) yazılımları ile yapıld1.

\section{Bulgular}

Yaş ortalaması $60.81 \pm 9.93$ yıl $(38-87 y)$ olan 79 erkek ve 11 kadın hastanın verileri analiz edildi. Tercih edilen cerrahi yaklaşım 12 (\%13.33) hastada VATS idi [grup 1: $n=4$ (\%13.33), grup 2: $n=8$ (\% 13.33), $\mathrm{p}=1.000]$. Histopatolojik incelemede tümör tipi 41 (\%45.56) hastada skuamöz hücreli karsinom, 28 (\%31.11) hastada adenokarsinom ve 21 (\%23.33) hastada diğer hücre tipinde karsinomlar görüldü. TNM sınıflandırmasının 8. baskısına göre 57 (\%63.33) hasta evre I, 23 (\% 25.56) hasta evre II ve 10 (\% 11.11) hastada evre III ve IV olarak saptand1. Ortalama tümör boyutu $2.94 \pm 1.26 \mathrm{~cm}$ (min-maks: 0.2-5.5) idi, 22 hastada $2 \mathrm{~cm}$ veya daha küçük tümör vardı. Lenf nodu metastazlar1 (N1 veya N2) grup 1'deki rın \%13.33'ünde ve grup 2'de \%16.67'sinde doğrulandı ( $\mathrm{p}=0.767)$. Otuz bir hastaya adjuvan tedavi verildi [grup 1: $n=10,(\% 33.33)$, grup $2: n=21$ (\% 35.00), $p=$ 1.000]. İki grup arasında cinsiyet, ortalama FEV1, tümör histolojik tipi, tümör boyutu, lenf nodu metastazı, hastanede kalış süresi, evre dağılımı ve adjuvan tedavi açısından istatistiksel fark yoktu (Tablo I).

Tablo I. Hasta özellikleri

\begin{tabular}{|c|c|c|c|c|}
\hline Değişkenler & $\begin{array}{c}\text { Total } \\
(\mathrm{n}=90)\end{array}$ & $\begin{array}{c}\mathrm{TS} / \mathrm{L} \\
(\mathrm{n}=30)\end{array}$ & $\begin{array}{c}\text { ÜL } \\
(n=60)\end{array}$ & $\begin{array}{c}\mathrm{p}- \\
\text { value }\end{array}$ \\
\hline Yaş & $60.81 \pm 9.93$ & $60.90 \pm 9.71$ & $60.77 \pm 10.13$ & 0.953 \\
\hline Cinsiyet Erkek & $79(\% 87.78)$ & $27(\% 90)$ & $52(\% 86.67)$ & \multirow[t]{2}{*}{0.746} \\
\hline Kadın & $11(\% 12.22)$ & $3(\% 10)$ & $8(\% 13.33)$ & \\
\hline FEV1 (L) & $216.09 \pm 70.07$ & $211.50 \pm 93.40$ & $218.31 \pm 57.44$ & 0.805 \\
\hline FEV1 (\%) & $75.33 \pm 19.84$ & $69.79 \pm 24.46$ & $78.00 \pm 0.3$ & 0.272 \\
\hline $\begin{array}{l}\text { Histopatolojik tip } \\
\text { Adenokarsinom }\end{array}$ & $28(\% 31.11)$ & $9(\% 30.00)$ & $19(\% 31.67)$ & \multirow{3}{*}{0.869} \\
\hline Skuamöz hücreli karsinom & $41(\% 45.56)$ & $13(\% 43.33)$ & $28(\% 46.67)$ & \\
\hline Diğerleri & $21(\% 23.33)$ & $8(\% 26.67)$ & $13(\% 21.67)$ & \\
\hline VATS & $12(\% 13.33)$ & $4(\% 13.33)$ & $8(\% 13.33)$ & 1.000 \\
\hline Lenf Nodu & $76(\% 84.44)$ & $26(\% 86.67)$ & $50(\% 83.33)$ & \multirow{3}{*}{1.000} \\
\hline N1 & $7(\% 7.78)$ & $2(\% 6.67)$ & $5(\% 8.33)$ & \\
\hline N2 & $7(\% 7.78)$ & $2(\% 6.67)$ & $5(\% 8.33)$ & \\
\hline pEvre I IA1 & $13(\% 14.4)$ & $5(\% 16.7)$ & $8(\% 13.3)$ & \multirow{7}{*}{0.81} \\
\hline IA2 & $15(\% 16.7)$ & $4(\% 13.3)$ & $11(\% 18.3)$ & \\
\hline IA3 & $17(\% 18.9)$ & $8(\% 26.7)$ & $9(\% 15)$ & \\
\hline IB & $12(\% 13.3)$ & $1(\% 3.3)$ & $11(\% 18.3)$ & \\
\hline pEvre II IIA & $8(\% 8.9)$ & $1(\% 3.3)$ & 7 (\%11.7) & \\
\hline IIB & $15(\% 16.7)$ & $6(\% 20)$ & $9(\% 15.0)$ & \\
\hline IIIA-B-IV & $10(\% 11.1)$ & $5(\% 16.7)$ & $5(\% 8.3)$ & \\
\hline Tümör çapı (cm) & $2.94 \pm 1.26$ & $3.01 \pm 1.21$ & $2.91 \pm 1.29$ & 0.743 \\
\hline Adjuvan tedavi n (\%) & $31(\% 34.44)$ & $10(\% 33.33)$ & $20(\% 66.67)$ & 1.000 \\
\hline $\begin{array}{l}\text { Hastanede kalış süresi } \\
\text { (gün)* }\end{array}$ & $6(0: 16)$ & $6(0: 114)$ & $6(0: 16)$ & 0.450 \\
\hline
\end{tabular}

TS: trisegmentektomi, L: Lingulektomi, ÜL:üst lobektomi, E: erkek, K:kadın, FEV1: Birinci Saniyedeki Zorlu Ekspiratuar Volüm, VATS: video-yardımlı torakoskopik cerrahi, L:litre. Veriler ortalama \pm standart sapma, medyan (min: maks) veya n (\%) olarak sunuldu

Otuz dört (\%37.78) hastada [grup 1: n=11 (\%36.67), grup 2: 23 (\%38.33), p=1.000] komplikasyon görüldü. En s1k görülen komplikasyon UHK (\%17.7) idi. Cerrahi işlem sonrası komplikasyonlar Tablo II'de listelenmiştir. Mortalite oranı tüm gruplarda 30 günlük \%1.11 [grup 1: $n=1$ (\% 3.33), grup 2: $n=0$ (\% 0), p $=0.333$ ], 90 günlük ise $\% 3.33$ [grup $1: \mathrm{n}=1$ (\%3.33), grup 2: $n=2$ (\% 3.33), $\mathrm{p}=1.000$ ] olarak saptand1. Sınırlı akciğer rezervi olan 79 yaşındaki bir hastaya (FEV1=0.90L, \%37) lingulektomi yapıldı ve 27 gün süren UHK gelişti. Hasta pnömoni ve septisemi nedeniyle ex oldu. Diğer iki hasta problemsiz geçen postoperatif erken dönem sonrası taburcu edildi. Bir hasta lobektomiden 2 ay sonra pnömoni ve adjuvan kemoterapi alan başka bir hasta ameliyattan 2 ay sonra intrakraniyal kanama nedeniyle ex oldu. Toplam 5 yıllık sağkalım oranı \%61.47 idi (grup 1: \%56.98; grup 2: \%64.05). Grup 1 için ortalama Kaplan-Meier sağkalım süresi 113.61 (\% 95 CI: 80.71-146.52) ve grup 2 için 105.84 (\% 95 CI: 81.98-129.70) idi. Sağkalım süresi açısından gruplar arasında istatistiksel fark yoktu ( $\mathrm{p}=0.780)$. Evre I hastalar için beş yıllık 


\section{H. Melek, ark.}

sağkalım oranı \%70.87 idi [grup 1: \%75.83, grup 2: \%67.61]. Evre I hastalarda ortalama Kaplan-Meier sağkalım süresi grup 1 için 146.09 (\% 95 CI: 111.70180.49) ve grup 2 için 106.99 (\% 95 CI: 77.68136.30) idi. Evre I hastalarda sağkalım süresi açısından gruplar arasında istatistiksel olarak fark yoktu ( $\mathrm{p}=$ $0.185)$ (Şekil 1-2). Squamöz hücreli karsinom $(p=0.5)$ ve adenokarsinom $(\mathrm{p}=0.4)$ alt tiplerine göre sağ kalım analizinde gruplar arasında fark saptanmadı.

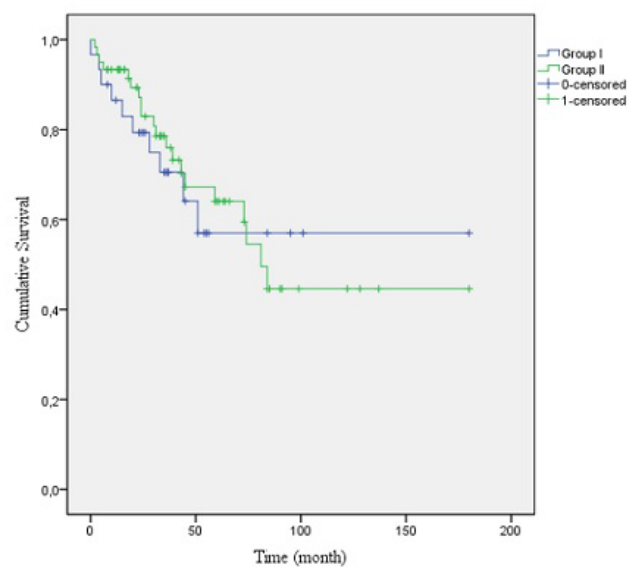

Şekil 1.

Kaplan-Meier eğrileri, trisegmentektomi-lingülektomi ve sol üst lobektomi uygulanan hastaların genel săgkalımlarını karşılaştırır. Gruplar arasında sağkalım oranlarında fark yok

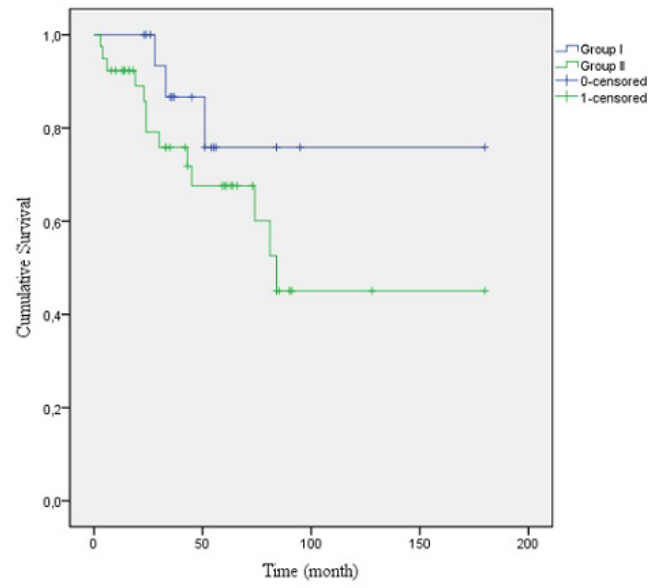

Şekil 2.

Kaplan-Meier ĕgrileri, Evre I KHDAK için trisegmentektomi-lingülektomi ve sol üst lobektomi uygulanan hastaların genel sağkalımlarını karşılaştırır. Gruplar arasında sağ kalım oranlarında fark yok

Takiplerde bir hastada (\%1.11) lokal nüks görüldü. Segmentektomi grubunda lokal nüks görülmezken, lobektomi grubunda \%1.67 oranında görüldü. Sadece evre I hastalar incelendiğinde, lokal nüks oranı \%1.75 idi. Lokal rekürrens açısından iki grup arasında anlaml1 fark yoktu $(\mathrm{p}=1.000)$. Uzak nüks oranı gruplar arasında benzerdi (Tablo II).
Tablo II. Postoperatif komplikasyonlar, gruplarda nüks

\begin{tabular}{|rr|ccc|c|}
\hline Değişkenler & $\begin{array}{c}\text { Total } \\
(\mathrm{n}=90)\end{array}$ & $\begin{array}{c}\mathrm{TS} / \mathrm{L} \\
(\mathrm{n}=30)\end{array}$ & $\begin{array}{c}\text { ÜL } \\
(\mathrm{n}=60)\end{array}$ & $p$-value \\
\hline Komplikasyonlar & $\mathrm{n}(\%)$ & $\begin{array}{c}34 \\
(\% 37.78)\end{array}$ & $\begin{array}{c}11 \\
(\% 36.67)\end{array}$ & $\begin{array}{c}23 \\
(\% 38.33)\end{array}$ & 1.000 \\
\hline $\begin{array}{r}\text { Uzamış hava kaçağı (>5 } \\
\text { gün) }\end{array}$ & 16 & 5 & 11 & \\
\hline Pnömoni & 7 & 3 & 4 & \\
\hline Plevral boşluk & 9 & 3 & 6 & \\
\hline Atelektazi & 5 & 2 & 3 & \\
\hline Aritmi & 2 & - & 2 & \\
\hline Diğerleri & 5 & 1 & 4 & \\
\hline Mortalite & $\mathrm{n}(\%)$ & $1(\% 1.11)$ & $1(\% 3.33)$ & - & 0.333 \\
\hline Ev gün mortalite & $\mathrm{n}(\%)$ & $3(\% 3.33)$ & $1(\% 3.33)$ & $2(\% 3.33)$ & 1.000 \\
\hline Evre I nüks & $\mathrm{n}(\%)$ & $7(\% 12.28)$ & $3(\% 16.67)$ & $4(\% 10.26)$ & 0.667 \\
\hline Evre I lokal nüks & $\mathrm{n}(\%)$ & $1(\% 1.75)$ & - & $1(\% 2.56)$ & 1.000 \\
\hline
\end{tabular}

TS: trisegmentektomi, L: Lingulektomi, ÜL: Üst lobektomi Veriler n (\%) olarak sunuldu.

\section{Tartışma ve Sonuç}

Lobektomi, KHDAK tedavisinde altın standart cerrahi prosedürdür. Düşük kardiyopulmoner fonksiyon nedeniyle lobektomiyi tolere edemeyen hastalarda, en iyi cerrahi seçenek segmentektomidir. Yirmi dört farklı segmentektomi tanımlanmıştır. Trisegmentektomi (TS), anatomik farklılıklardan dolayı segmentektomi olarak tanımlansa da aslında sağ üst lobektomiye eşittir ve sol akciğer segmentektomilerinin \%24'ünü oluşturur $^{8-10}$. Lobektomiye alternatif olarak TS yapılmasında ki en önemli amaç, linguler segmentin pulmoner fonksiyonunu korumaktır ${ }^{8}$. Ancak klinik olarak sol üst lobektomiye eş değer kabul edilebilmesi için onkolojik sonuçlarla desteklenmesi gerekir. Son y1llarda parankim koruyucu ameliyatların erken evre akciğer kanseri için daha popüler hale gelmesiyle segmentektomi ve lobektomi sonuçlarını karşılaştıran bir dizi çalışma yayınlandı. Lobektomi ile kıyaslandığında segmentektominin en büyük dezavantajı yüksek nüks oranlarıdır². Akciğer rezeksiyonu sonrası nüks, beklenen uzun vadeli sağkalımda keskin bir düşüşe yol açan en sik nedendir ${ }^{11}$. Segmentektomi sonrası lokal nüksler, yetersiz cerrahi sınır, aynı lobda intrapulmoner metastazin ve hiler-mediastinal lenf nodu metastazının tanınmaması nedeniyle olabilir ${ }^{12}$. Segmentektomi sonrası lokal nüksü belirlemede en önemli faktör rezeksiyon sınırıdır ${ }^{3,12}$. Sağ üst lob tümörlerinde minör fissür invazyonlarında bilobektomi tercih edilir. Benzer şekilde TS apikal yerleşimli tümörlere uygulanmalı ve cerrahi sinır $1 \mathrm{~cm}$ 'den az ise lobektominin TS'ye tercih edilmesi savunulmaktadir ${ }^{3}$. VATS veya torakotomi ile yapılan segmentektomi veya lobektomi sonrası lokal nüks oranları, evre Ia için birçok çalışmada yayınlandığı gibi yaklaşık \%3-5 ile neredeyse benzerdir $^{9,13,14}$. Serimizde TS/L veya lobektomi sonrası nüks oranı benzer olmakla birlikte, lokal nüks sade- 


\section{Sol Üst Lobektomi Evre I KHDAK İçin Aşırı Tedavi mi?}

ce lobektomi grubunda evre I'de görülmüştür. $\mathrm{Bu}$ bulgunun açıklaması, segmentektomi sonrası yetersiz parankimal cerrahi sinır varsa lobektomi yapılmasi olabilir.

Patolojik N1 ve N2 hastalık olasılığ1 (pN1-2) klinik Evre I KHDAK'de düşüktür. Japon Akciğer Kanseri Kayıt Çalışmasında, cT1N0M0 akciğer karsinomu olan hastalarda \%10 lenf nodu metastazı tespit edildiği bildirilmiştir ${ }^{15}$. Ancak segmentektomi uygulanan olgularda nüks olasılığının artması nedeniyle bronş çevresinde intraoperatif lenf nodu pozitifliği olması durumunda lobektomi yapılması önerilir. Bu bakımdan intraoperatif sentinal lenf nodu tespit yöntemleri ve frozen inceleme faydalı olabilir. Nomori $\mathrm{H}$ ve arkadaşları, segmentektomi sırasında frozen kesitlerinde lenf düğümlerinin negatif sonuçlanmasına rağmen, nihai patoloji raporunda rezeke edilen akciğer dokusunda lenf nodu metastazları ortaya çıkarsa, tamamlayıcı lobektominin gerekliliğini araştırdı. $\mathrm{Bu}$ nedenle lokal rekürrensi azaltmak için 10 tamamlayıcı lobektomi yaptılar ancak kalan akciğer dokusunda metastaz izlenmedi. Böylelikle, cT1N0M0 / pN1-2 KHDAK hastalarında lobektomide olduğu gibi aynı lokal kontrolü sağladığından, lenf nodu diseksiyonu ile birlikte yeterli cerrahi sınırlar elde edildiğinde segmentektomiden sonra tamamlayıcı lobektominin gereksiz olduğu sonucuna varmışlardır ${ }^{12}$. Çalışmamızda TS / L grubunda pN2'li iki hasta ve pN1 lenf nodu metastazı olan iki hasta saptandi. Ancak bu hastalara tamamlay1c1 lobektomi yapılmadi. pN1 hastalarına adjuvan kemoterapi, pN2 hastalarına kemoradyoterapi verildi. pN2 hastalarından biri 44 ay sonra kraniyal metastaz nedeniyle, diğeri 20 ay sonra akut miyokard enfarktüsü nedeniyle ex oldu. pN1 lenf nodu metastazı olan hastalar sirasiyla ameliyattan 45 ve 16 ay sonra hastaliksız olarak takip edilmektedir.

Akciğer kanseri 8. TNM Evreleme sisteminde; tümör çapındaki her bir santimetrelik artışın daha kötü prognoz göstergesi olması nedeniyle 5 cm'ye kadar olan tümör boyutları her bir santimetrede bir kademe yükselecek şekilde beş gruba ayrıldı (T1a, T1b, T1c, T2a, $\mathrm{T} 2 \mathrm{~b})^{16}$.Tümör boyutunun anatomik akciğer rezeksiyonu sonrası sonuçlara etkisini araştıran çalışmalarda ise farklı sonuçlara ulaşıldı. Yu ve arkadaşları tümör boyutu 21-30 mm olan hastalarda segmental rezeksiyonun daha kötü sağkalım ile ilişkili olduğu için lobektomi yapılması önerdiler ${ }^{17}$. Diğer çalışmalarda ise segmentektomi ile lobektomi arasında benzer sonuçlar elde edildi ${ }^{18,19}$. Sadece sol üst lob yerleşimli tümörleri içeren bir çalışmada TS/L ve sol üst lobektomi sonuçları karşılaştırılmış, TS/L'nin T1 tümörler yanında T2N0 tümörlerde de benzer onkolojik sonuçlara yol açtığı ve akciğer fonksiyonu iyi olan hastalarda bile lobektomiye alternatif olarak kullanılabileceği belirtilmiştir ${ }^{20}$. Bizde çalışmamızda da benzer sonuçlara ulaştık. Ancak tümör çapına göre alt gruplar arasında sağ kalım analizi yapabilmek için mevcut hasta say1- mız yeterli değildi. Ayrıca çalışmamızda hücre tipine göre sağ kalım farkı saptanmadı.

Segmentektominin onkolojik sonuçlarına ek olarak olası avantaj ve dezavantajları da tartışılmalıdır. Literatürde segmentektominin lobektomi ile karşılaştırıldığında akciğer fonksiyonu üzerinde herhangi bir yararlı etkisinin olmadığını gösteren bazı çalışmaların aksine $^{21}$, segmentektominin daha avantajlı olduğu ve akciğer fonksiyonunun korunmasına katkıda bulunduğu şeklinde genel fikir birliği mevcuttur ${ }^{22-24}$. Küratif tedaviden sonra yeni akciğer kanseri gelişme riski \%1$6{ }^{\prime} d ı r^{25}$. Günümüzde metakron akciğer tümörü sıklığ 1 artmaktadır. Gelişmiş tarama teknikleri nedeniyle, erken evre akciğer kanseri insidansı artmış ve bu hastalarda iyi cerrahi sonuçlar elde edilmiştir. İlk hastalıktan kurtulan hastalar için ikincil bir hastalık geliştirme riski daha yüksektir. Bu nedenlerle ilk ameliyat olarak solunum fonksiyonlarını koruyucu segmentektomi yapmak, gelecekte ikinci bir cerrahi firsatı sunabilir $^{22}$.

Lobektomiye göre segmentektominin dezavantajlarından biri teknik olarak daha zor olmasıdır. TS ve sağ üst lobektomiyi anatomik olarak birbirine eşdeğer kabul ederken, TS ve sağ üst lobektomiyi birbirinden ayıran en önemli faktörlerden biri, sol tarafta minör fissür olmadığı için lingula segmentinden ayrımını yapmaktır. Lobektomi sırasında fissürü ayırmak için sıklıkla stapler kullanılır. Bununla birlikte, segmentektomilerde segmental planın ayrılması sırasında, stapler telleri kalan segmentin parankimini sıkıștırabilir ve mevcut parankimal ventilasyonu bozabilir ${ }^{26}$. Bazı yazarlar, segmentlerin stapler veya başka yollarla ayrılmasında bir fark olmadığını iddia etmektedir ${ }^{27}$. Biz daha az hava kaçağına yol açtığı için segmentasyon için stapler kullanıyoruz ${ }^{5,28}$. Çalışmamızda TS/L grubunda 5 (\%16.6) hastada UHK ve 3 (\%10) hastada plevral boşluk izlendi. Bu komplikasyonlar nedeniyle cerrahi müdahale uygulanmadı. Birçok cerrah VATS ile segmentektomi yapılmasının zor olduğuna inanmasına rağmen, teknik olarak uygulanabilir olduğu birçok kez kanıtlanmıştır. Çalışmalarda, VATS'ın evre I KHDAK için güvenli ve etkili olduğu gösterilmiştir ${ }^{5,6}$. Biz de son y1llarda segmentektomi için VATS' ${ }_{1}$ tercih etmekteyiz.

Literatürde TS'nin sonuçlarını sol üst lobektomi ile karşılaştıran çok az çalışma vardır. Bu çalışmalar klinik ve onkolojik sonuçlarımızı desteklemekte$\operatorname{dir}^{6,20,29,30}$. Iwasaki A ve arkadaşları, çapı 2 cm'den küçük olan ve sol üst bölümde yer alan tümörler ile evre I KHDAK için bir çalışma yürüttüler ve çalışmaya 86 hastayı dahil ettiler. Otuz bir hastaya TS, 55 hastaya lobektomi yapıldı. TS grubundaki hastalarda daha düşük FEV1 değerine sahipti ve yaş olarak daha yaşlıydı, ancak morbidite ve mortalite açısından iki grup arasında fark bulunmadi. TS'li hastalarda nüks oranı \%3.2, beş yıllık sağkalım oranı \% 69.7 ve lobektomi hastalarında sirasıyla bu oranlar \%3.6 ve \%72.5 


\section{H. Melek, ark.}

olarak sonuçlandı. Yazarlar, TS'nin apikal tümörler için standart tedavi olabileceği sonucuna varmışlar$\mathrm{d}_{1} \mathrm{r}^{29}$. Başka bir çalışma, sol akciğer apikal lokalizasyonu olan küçük boyutlu akciğer kanseri için lingula rezeksiyonunun gereksiz olduğunu ve TS sonrası sağkalım oranlarının evre IA ve IB hastalığı için lobektomiye benzer olduğunu bildirmiştir ${ }^{10}$. Witte $B$ ve arkadaşları tarafindan yapılan bir çalışma. $2 \mathrm{~cm}$ 'den büyük tümör çaplarının, nodal tutulumun ve önceki neoadjuvan tedavinin, titiz bir nodal diseksiyon koşulu altında seçilmiş hastalar için bu seçeneği mutlaka dışlamadığı sonucuna varmıştır ${ }^{30}$. Çalışmamızda TS uygulanan 18/30 hastada evre I hastalık mevcuttu. TS'nin küçük çaplı sol üst apikal segmental KHDAK için standart cerrahi rezeksiyon olduğu konusunda hemfikiriz $^{6,20}$.

Sonuç olarak güncel kanaat, klinik evre I hastalığın standart cerrahi tedavisi olan lobektomi sonuçları ile karşılaştırıldığında, anatomik segmentektomi sonuçlarının perioperatif morbidite/mortalite, nüks ve sağkalıma bakıldığında farkın istatistiksel olarak önemsiz olmasıdır. $\mathrm{Bu}$ nedenle, seçilmiş hastalarda sol üst lobektomiye alternatif olarak anatomik TS/L düşünülmelidir.

Etik Kurul Onay Bilgisi:

Onaylayan Kurul: Uludağ Üniversitesi Tıp Fakültesi Klinik Araştırmalar Etik Kurulu.

Onay Tarihi: 27.05.2020

Karar No: 2020-9/20

Araştırmacı Katkı Beyanı: Fikir ve tasarım: H.M.; Veri toplama ve işleme: H.M., T.E.S.; Analiz ve verilerin yorumlanmass: H.M., D.S.; Makalenin önemli bölümlerinin yazılması: H.M., T.E.S., D.S., A.S.B., C.G.

Destek ve Teşekkür Beyanı: Çalışmamızda herhangi bir finansal destek alınmamıștır.

Çıkar Çatışması Beyanı: Makale yazarının çıkar çatışması beyan yoktur.

\section{Kaynaklar}

1. Van Schil PE, Balduyck B, De Waele M, Hendriks JM, Hertoghs M, Lauwers P. Surgical treatment of early-stage nonsmall-cell lung cancer. EJC Suppl. 2013 Sep;11(2):110-22.

2. Ginsberg RJ, Rubinstein LV. Randomized trial of lobectomy versus limited resection for T1 N0 non-small cell lung cancer. Lung Cancer Study Group. Ann Thorac Surg 1995;60:615-22; discussion 622-3.

3. Sienel W, Stremmel C, Kirschbaum A, Hinterberger L, Stoelben E, Hasse J, et al Frequency of local recurrence following segmentectomy of stage IA non-small cell lung cancer is influenced by segment localisation and width of resection margins-implications for patient selection for segmentectomy. Eur J Cardiothorac Surg. 2007 Mar;31(3):522-7.

4. https://www.nccn.org/professionals/physician_gls/pdf/nscl.pdf

5. Gossot D. Totally thoracoscopic left upper lobe trisegmentectomy. Ann Cardiothorac Surg. 2014 Mar;3(2):197201.
6. Houck WV, Fuller CB, McKenna RJ Jr. Video-assisted thoracic surgery upper lobe trisegmentectomy for early-stage left apical lung cancer. Ann Thorac Surg. 2004 Nov;78(5):1858-60. Review

7. Landreneau RJ, Normolle DP, Christie NA, Awais O, Wizorek $\mathrm{JJ}$, Abbas $\mathrm{G}$ et al. Recurrence and survival outcomes after anatomic segmentectomy versus lobectomy for clinical stage I nonsmall-cell lung cancer: a propensity-matched analysis. J Clin Oncol. 2014 Aug 10;32(23):2449-55.

8. Nomori H, Okada M, editors. Illustrated Anatomical Segmentectomy for Lung Cancer. Springer 2012, ISBN 978-4-43154143-1

9. Okada M, Mimae T, Tsutani Y, Nakayama H, Okumura S, Yoshimura M, Miyata Y. Segmentectomy versus lobectomy for clinical stage IA lung adenocarcinoma. Ann Cardiothorac Surg. 2014 Mar;3(2):153-9

10. Soukiasian HJ, Hong E, McKenna RJ Jr. Video-assisted thoracoscopic trisegmentectomy and left upper lobectomy provide equivalent survivals for stage IA and IB lung cancer. J Thorac Cardiovasc Surg. 2012 Sep;144(3):S23-6.

11. Dziedzic DA, Rudzinski P, Langfort R, Orlowski T; Polish Lung Cancer Study Group (PLCSG). Risk Factors for Local and Distant Recurrence After Surgical Treatment in Patients With Non-Small-Cell Lung Cancer. Clin Lung Cancer. 2016. pii: S1525- 7304(16)00003-6.

12. Nomori $H$, Mori T, Izumi $Y$, Kohno M, Yoshimoto K, Suzuki M. Is completion lobectomy merited for unanticipated nodal metastases after radical segmentectomy for cT1 N0 M0/pN1-2 non-small cell lung cancer? J Thorac Cardiovasc Surg. 2012 Apr;143(4):820-4.

13. Zhong C, Fang W, Mao T, Yao F, Chen W, Hu D. Comparison of thoracoscopic segmentectomy and thoracoscopic lobectomy for small-sized stage IA lung cancer. Ann Thorac Surg. 2012 Aug;94(2):362-7.

14. Bao F, Ye P, Yang Y, Wang L, Zhang C, Lv X, Hu J. Segmentectomy or lobectomy for early stage lung cancer: a metaanalysis. Eur J Cardiothorac Surg. 2014 Jul;46(1):1-7.

15. Sawabata N, Miyaoka E, Asamura H, Nakanishi Y, Eguchi K, Mori M, et al. Japanese Lung Cancer Registry Study of 11,663 surgical cases in 2004: demographic and prognosis changes over decade. J Thorac Oncol. 2011;6:1229-35

16. Rami-Porta R, Bolejack V, CrowleyJ, et al. The IASLC Lung Cancer Staging Project: Proposals for the Revisions of the T Descriptors in the Forthcoming Eighth Edition of the TNM Classification for Lung Cancer. J Thorac Oncol 2015; 10(7): 990-1003

17. Yu X, Zhang R, Zhang M, Lin Y, Zhang X, Wen Y, et al; written on behalf of the AME Thoracic Surgery Collaborative Group. Segmental resection is associated with decreased survival in patients with stage IA non-small cell lung cancer with a tumor size of 21-30 mm. Transl Lung Cancer Res. 2021 Feb;10(2):900-913. doi: 10.21037/tlcr-20-1217. PMID: 33718031; PMCID: PMC7947415.

18. Carr SR, Schuchert MJ, Pennathur A, Wilson DO, Siegfried JM, Luketich JD, et al. Impact of tumor size on outcomes after anatomic lung resection for stage $1 \mathrm{~A}$ non-small cell lung cancer based on the current staging system. J Thorac Cardiovasc Surg. 2012 Feb;143(2):390-7. doi: 10.1016/j.jtcvs.2011.10.023. Epub 2011 Dec 9. PMID: 22169444.

19. Chan EG, Chan PG, Mazur SN, Normolle DP, Luketich JD, et al. Outcomes with segmentectomy versus lobectomy in patients with clinical T1cN0M0 non-small cell lung cancer. J Thorac Cardiovasc Surg. 2021 May;161(5):1639-1648.e2. doi: 10.1016/j.jtcvs.2020.03.041. Epub 2020 Mar 23. PMID: 32331817.

20. Aprile V, Bertoglio P, Dini P, Palmiero G, Mussi A, Ambrogi MC, et al. Is left upper lobectomy always worthwhile for early stage lung cancer? A comparison between left upper lobectomy, 


\section{Sol Üst Lobektomi Evre I KHDAK İçin Aşırı Tedavi mi?}

trisegmentectomy, and lingulectomy. J Surg Oncol. 2018 Mar;117(4):618-624. doi: 10.1002/jso.24884. Epub 2017 Oct 19. PMID: 29049856.

21. Takizawa T, Haga M, Yagi N, Terashima M, Uehara H, Yokoyama A, et al. Pulmonary function after segmentectomy for small peripheral carcinoma of the lung. J Thorac Cardiovasc Surg. 1999 Sep;118(3):536-41.

22. Harada H, Okada M, Sakamoto T, Matsuoka H, Tsubota N. Functional advantage after radical segmentectomy versus lobectomy for lung cancer. Ann Thorac Surg. 2005 Dec;80(6):2041-5

23. Keenan RJ, Landreneau RJ, Maley RH Jr, Singh D, Macherey $\mathrm{R}$, Bartley S, et al. Segmental resection spares pulmonary function in patients with stage I lung cancer. Ann Thorac Surg 2004;78:228-33.

24. Kobayashi N, Kobayashi K, Kikuchi S, Goto Y, Ichimura H, Endo K, Sato Y. Long-term pulmonary function after surgery for lung cancer. Interact Cardiovasc Thorac Surg. 2017 May 1;24(5):727-732

25. Loukeri AA, Kampolis CF, Ntokou A, Tsoukalas G, Syrigos K. Metachronous and synchronous primary lung cancers: diagnostic aspects, surgical treatment, and prognosis. Clin Lung Cancer 2015;16(1):15-23.
26. Asakura K, Izumi Y, Kohno M, et al. Effect of cutting technique at the intersegmental plane during segmentectomy on expansion of the preserved segment: comparison between staplers and scissors in ex vivo pig lung. Eur J Cardiothorac Surg 2011;40:e34-8.

27. Miyasaka Y, Oh S, Takahashi N, et al. Postoperative complications and respiratory function following segmentectomy of the lung - comparison of the methods of making an inter-segmental plane. Interact Cardiovasc Thorac Surg 2011;12:426-9

28. Ojanguren A, Gossot D, Seguin-Givelet A. Division of the intersegmental plane during thoracoscopic segmentectomy: is stapling an issue? J Thorac Dis. 2016 Aug;8(8):2158-64.

29. Iwasaki A, Hamanaka W, Hamada T, Hiratsuka M, Yamamoto S, Shiraishi T, Shirakusa T. Comparison between a casematched analysis of left upper lobe trisegmentectomy and left upper lobectomy for small size lung cancer located in the upper division. Thorac Cardiovasc Surg. 2007 Oct;55(7):454-7.

30. Witte B, Wolf M, Hillebrand H, Huertgen M. Split-lobe resections versus lobectomy for lung carcinoma of the left upper lobe: a pair-matched case-control study of clinical and oncological outcomes. Eur J Cardiothorac Surg. 2014 Jun;45(6):1034-9. 
